Vol. 4: 351-361.

\title{
Comparison of production results between blue foxes housed with and without platforms
}

Hannu Korhonen and Paavo Niemelä

\author{
Agricultural Research Centre of Finland, Fur Farming Research Station, FIN-69100 Kannus, Finland
}

\begin{abstract}
The production results of farmed blue foxes (Alopex lagopus) housed in cages with and without resting platforms were compared. No differences in weight gain or reproductive performance were found between the groups. However, locomotor activity prior to the breeding season tended to be slightly lower in animals provided with platforms. Platform use during the period of winter fur development (Oct-Nov) varied for the different platform constructions, being highest in wooden U-type platforms placed $30 \mathrm{~cm}$ from the cage roof $(54.1 \%$ of observations on platforms) and lowest in the corner platform type $(12.6 \%, \mathrm{p}<0.001)$. Use of platforms made of wire mesh $(45.2 \%)$ did not differ significantly from that of the wooden U-types. Ceiling and construction material affected platform dirtiness. The proportion of clean platforms was lowest (35.7\%) when the platform was $30 \mathrm{~cm}$ from the roof. Net platforms remained very clean throughout the study. The time required for cleaning was greatest in August, ranging from 82 seconds/platform/week for the U-30 type to 2 seconds for the net type. Fur quality $(\mathrm{p}<0.001)$ and clarity $(\mathrm{p}<0.001)$ had a significant, but negative, correlation with platform dirtiness. The condition of almost all the wooden platforms deteriorated over time due to chewing. Wire mesh platforms were not chewed on. From the farmer's point of view, wire mesh seems to be preferable to wood as a platform material.
\end{abstract}

Key words: Farm fox, production performance, resting shelves, enrichment, welfare

\section{Introduction}

Unlike that of many other species of domestic animals, the design of the housing environment employed in fur-bearing animal production has not changed greatly over the years. Traditionally, farmed blue foxes (Alopex lagopus) have been housed in bare wire-mesh cages without any shelter other than the shed. Nestboxes have been supplied only to females during pregnancy and lactation. This housing system has proved to be economically successful. Some farmers have, however, occasionally provided seasonal or whole-year shelters such as resting platforms, sleeping ledges or nestboxes for their foxes, with variable results (Harri et al. 1992, Valtonen and Moss 1983). There is also positive, experimental evidence that farmed foxes with access to whole-year shelters show a lower level of stress and fear than animals without access (Jeppesen and Pedersen 1991, 1992). 
Korhonen, H.\& Niemelä, P.: Comparison of production results between blue foxes housed with and without platforms

The recent recommendations issued by the European Convention for animal protection include the provision that for each weaned fox there should be available a secluded area which it can use for resting, observing and hiding (European Convention 1991). In practice, this means that each farm cage should be equipped with a resting platform or nestbox. At present, however, compliance with the recommendations is not unambiguous, first, because of the lack of commonly accepted platform construction designs despite several studies (e.g. Harri et al. 1991, Mononen et al. 1993, Pedersen and Jeppesen 1993, Korhonen and Niemelä 1994, Korhonen et al. 1995) and, second, because there is evidence suggesting that at least some construction models may even have some negative effects on production performance. For instance, the mass and fur quality of blue foxes were poorer in animals having had platforms since weaning than in those raised without platforms. There was also a negative correlation between fur quality and the amount of platform use (Korhonen and Niemelä 1993). In silver foxes, Harri et al. (1992) found that fur quality was adversely affected by access to whole-year shelters. Furthermore, the effect of the presence of platforms on the reproduction performance of farm-bred foxes requires more clarification because of the controversial whelping results reported elsewhere (KonnerupMadsen 1982, Valtonen and Moss 1983, Sönderup 1986). Thus, although there is general agreement that platforms and nestboxes can be of great importance for the welfare of farmed foxes (Braastad 1992, Bakken et al. 1994), the current recommendations of the European Convention need to be further investigated with regard to production performance.

The objective of the present study was to determine whether there is a difference between the production results of farm-raised blue foxes (Alopex lagopus) housed with and those housed without resting platforms. Therefore, whelping results, locomotor activity and body weight at the breeding season, development of body weight and platform damage in the growing period, and the degree of fur defects at pelting time were compared between the experimental groups.

\section{Material and methods}

\section{Platforms, animals and management}

The experiments were carried out at the Fur Farming Research Station of Kannus in 1993. The characteristics of the platform types used in the experiments are listed in Table 1 and schematic pictures are given in Fig.1. Wooden platforms were made of 5 " board (thickness $22 \mathrm{~mm}$ ) and wire mesh platforms of plastic-coated wire (1" x 1"). The bottoms of the $\mathrm{V}$ and $\mathrm{U}$ types were shaped like the letters $\mathrm{V}$ and $\mathrm{U}$. The $\mathrm{U}$ type also had a $45 \mathrm{~mm}$ thin strip of wood in the middle of the bottom. The front edge of the wire mesh platforms was fitted with a strip of wood ( $22 \mathrm{~mm} \mathrm{x}$ $45 \mathrm{~mm}$ ) for better stability. The platforms were placed in cages on both sides of the aisle.

Experiment 1 was carried out between February and July 1993 on adult blue foxes born in May 1992. Two groups were compared: (1) a control group, housed without platforms and (2) a platform group, housed with $\mathrm{V}$ type platforms. Both groups consisted of 60 females and 20 males. All animals of the platform group had previous platform experience of type $\mathrm{V}$ since their weaning (from July 1992 onwards); the controls had no previous experience. All adults were housed singly in wire-mesh cages measuring $107 \mathrm{~cm}$ wide x $120 \mathrm{~cm}$ long x $70 \mathrm{~cm}$ high.

Experiment 2 was carried out between July and November on 201 juvenile blue foxes (born May 1993; age <1 year). They were housed in two-row sheds with two animals occupying one wire-mesh cage measuring $107 \mathrm{~cm}$ wide $\mathrm{x} 120$ $\mathrm{cm}$ long $x 70 \mathrm{~cm}$ high. Each animal was eartagged for identification. All juveniles had preweaning platform experience. The experimental groups were as follows: (1) U-23 platform group: $\mathrm{U}$-shaped platform $23 \mathrm{~cm}$ from cage roof, (2) $\mathrm{U}$ 30 platform group: U-shaped platform $30 \mathrm{~cm}$ 


\section{AGRICULTURAL SCIENCE IN FINLAND}

Vol. 4: 351-361.

\section{V-23 U-23/30 Corner-23 Wire mesh-23}

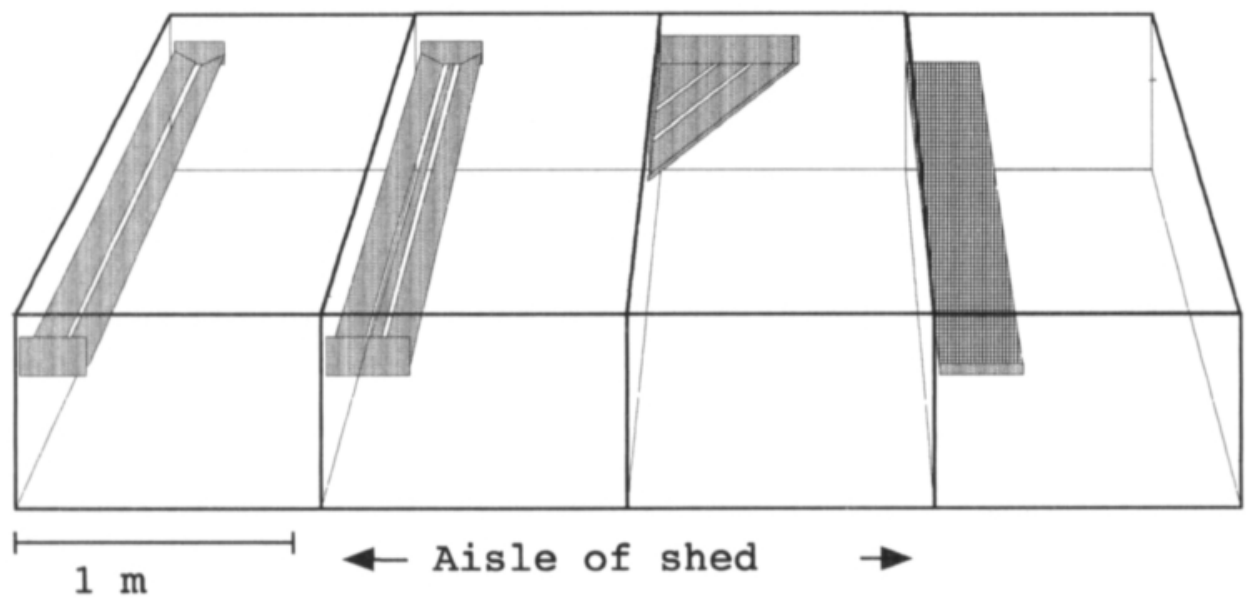

Fig. 1. Schematic pictures of platform types studied. For details see Table 1.

from cage roof, (3) Corner-23 platform group: flat bottom platform located at cage corner, 23 $\mathrm{cm}$ from cage roof, and (4) wire-mesh-23 platform group: wire-mesh platform $23 \mathrm{~cm}$ from cage roof (see Fig. 1).

Freshly mixed fox feed manufactured by the local feed kitchen was supplied twice a day at 9 am and $1 \mathrm{pm}$ from weaning to mid-September, and thereafter once a day at $1 \mathrm{pm}$. Feed portions (from $250 \mathrm{~g}$ in winter to $800 \mathrm{~g} / \mathrm{animal} /$ day during the growing period) were adjusted according to the seasonal standards of the Finnish Fur Breeders' Association (Berg 1986). Individual feed consumption, however, was not measured. The foxes were weighed each study month with a Lario $30 \mathrm{~kg}$ balance (accuracy $\pm 20 \mathrm{~g}$ ).

\section{Monitoring of platform use and activity}

Platform use was monitored with two methods:

(1) continuous 24-hour recording with video camera equipment (CCD video camera 720, Bische UB-480 tape recorder, Koyo monitor, Bische 12-300 infrared light: $500 \mathrm{~W}$ ) (Exp.1), and (2) daytime scanning observation made three times ( $8 \mathrm{am}, 12$ noon and $3 \mathrm{pm})$ each working day (Exp. 2) except Friday, when observations were made at 8 am and 12 noon only because of the shorter working day. The month was taken as the basic unit within which the platform use comparisons were made between groups. During the scan sampling the observer walked quietly and slowly past the row of cages and manually recorded the foxes' location (on platforms or not) (Pedersen and Jeppesen 1993). Thus,

Table 1. Characteristics of experimental platform types.

\begin{tabular}{lcccr}
\hline & $\mathrm{V}$ & $\mathrm{U}$ & Corner & Net \\
\hline $\begin{array}{l}\text { Experiment } \\
\text { Platform: }\end{array}$ & 1 & 2 & 2 & 2 \\
$\quad$ material & Wood & Wood & Wood & Wire $^{\mathrm{a}}$ \\
location & side & side & corner & side \\
bottom shape & $\mathrm{V}$ & $\mathrm{U}$ & flat & flat $^{\mathrm{b}}$ \\
ceiling, cm & 23 & $23 / 30$ & 23 & 23 \\
length, cm & 103 & 103 & $91^{\mathrm{d}}$ & 103 \\
width, cm & 25 & 30 & $65^{\mathrm{e}}$ & 30 \\
area, cm & 2580 & 3090 & 2050 & 3090 \\
wall height, cm & $12^{\mathrm{f}}$ & $12^{\mathrm{f}}$ & $12^{\mathrm{s}}$ & $\mathrm{h}$ \\
\hline
\end{tabular}

amade of plastic-coated wire, ${ }^{b}$ flexible when fox on it, ${ }^{c}$ distance of platform from cage roof, ${ }^{\mathrm{d}}$ hypotenuse, ${ }^{\circ}$ the two shorter sides of a right-angled triangle, ' at ends only, ${ }^{8}$ on shorter sides only, ${ }^{\text {h }}$ walls of wire mesh cage only. 


\section{AGRICULTURAL SCIENCE IN FINLAND}

Korhonen, H.\& Niemelä, P.: Comparison of production results between blue foxes housed with and without platforms

when standing in front of cage No. 2 the location of the fox in cage No.3 was recorded and so forth. If the fox fled from the observer, it's previous location was recorded.

The locomotor activity of the foxes was analysed from the continuous 24-hour video camera observations (Korhonen and Niemelä 1993). Both the control and platform groups were recorded for 20 days during each experimental month.

\section{Assessing fur parameters and platform conditions}

Urine staining and ventral fur wear were evaluated by two professionals at the Research Station. The evaluation scale and technique were the same as those used in our previous experiment (Korhonen and Niemelä 1993). The degree of ventral wear was assessed more strictly than in the normal assessment procedure used by Finnish Fur Sales Ltd. As well as furs originating from the experimental platform animals, 60 pelts were evaluated from animals housed without platforms. These were randomly selected from farm material and were used here as controls (only for urine staining and ventral wear). The control animals were housed in a similar manner to the experimental animals. Commercial fur parameters were evaluated by Finnish Fur Sales' professional graders (Fur Center, Vantaa). The scoring, which followed the rules of the Finnish Fur Breeders Association for experimental skin grading, was as follows (the lower the number, the poorer the fur quality and clarity and vice versa. Saga Royal, Saga etc. are the corresponding grading names used commercially in Scandinavia for experimental points (Einarsson and Skrede 1989, Finnish Fur Sales' auction catalogue 1994)): fur quality; $10=$ Saga Royal, $8=$ Saga, $6=$ quality class $1,3=$ quality class 2 and $1=$ quality class 3 . Clarity: $10=\mathrm{R}+$ excellent, $8=\mathrm{R}$ good, $6=\mathrm{R}$ medium, $4=\mathrm{OC}$ poor, $2=\mathrm{OC}$ very poor. Clarity is an expression of the shade of the colour (Einarsson and Skrede 1989).
Platform dirtiness was evaluated on a scale of $1-4$, where $1=$ clean, $2=$ slightly dirty, $3=$ moderately dirty, $4=$ very dirty (Korhonen and Niemelä 1993). Platforms were cleaned once a week. All cleaning times were recorded. The incidence of chewed platforms was checked at the same time.

\section{Statistical analysis}

Data were analysed using the SAS statistical programs (GLM procedure, NPAR IWAY procedure). Mean differences in body weight and activity were tested by analysis of variance (ANOVA), and the effects of advancing time by multivariate analysis of variance (MANOVA). Differences in platform use, fur defects and quality, and platform dirtiness between the groups were analysed by the Kruskal-Wallis one way analysis of variance and the Mann-Whitney U-test when comparing two groups. Regression analyses were employed to calculate the relationship between platform use and fur quality parameters, and between platform dirtiness and fur quality parameters. Whelping results were tested between two groups using the Mann-Whitney Utest.

\section{Results}

\section{Weight loss and activity during winter}

During the winter period from January to March (Exp. 1), the foxes spent only a short time on platforms, i.e. on average $54 \pm 13 \mathrm{~min} / 24 \mathrm{~h}$ (median $18 \mathrm{~min} / 24 \mathrm{~h}$ ). Table 2 presents changes in the body weights and locomotor activities of adult blue foxes selected for breeding. No statistically significant differences were found in the initial weights (Jan) between males in the control and platform groups. The trend continued unchanged until breeding time in midMarch. Among females, on the other hand, the 


\section{AGRICULTURAL SCIENCE IN FINLAND}

Vol. 4: 351-361.

Table 2. Body weight and locomotor activity in adult blue foxes (Exp. 1) during winter (mean \pm SD). ${ }^{*} \mathrm{p}<0.05$ (ANOVA). $\mathrm{N}=20$ for males and $\mathrm{N}=60$ for females in weighings and $\mathrm{N}=10$ for both sexes in video recorded measurements of locomotor activity. V-type platforms were used.

\begin{tabular}{|c|c|c|}
\hline & Control & Platform \\
\hline \multicolumn{3}{|l|}{ Body weight, kg } \\
\hline \multirow[t]{3}{*}{ males: } & $9.4 \pm 1.2$ & $8.9 \pm 1.4$ \\
\hline & $8.2 \pm 1.1$ & $8.2 \pm 1.1$ \\
\hline & $7.3 \pm 1.0$ & $7.2 \pm 0.9$ \\
\hline \multirow[t]{2}{*}{ females: } & $8.9 \pm 1.0$ & $7.9 \pm 1.0^{*}$ \\
\hline & $7.8 \pm 0.9$ & $7.3 \pm 0.9 *$ \\
\hline Mar 16 & $7.2 \pm 0.9$ & $6.8 \pm 0.9$ \\
\hline \multicolumn{3}{|c|}{ Locomotor activity, $\min / 24 \mathrm{~h}$} \\
\hline \multirow{3}{*}{ males: } & $237 \pm 99$ & $213 \pm 62$ \\
\hline & $327 \pm 124$ & $277 \pm 88$ \\
\hline & $445 \pm 178$ & $380 \pm 146$ \\
\hline \multirow[t]{2}{*}{ females: } & $278 \pm 73$ & $225 \pm 79$ \\
\hline & $233 \pm 61$ & $248 \pm 124$ \\
\hline March & $347 \pm 137$ & $253 \pm 69$ \\
\hline
\end{tabular}

animals with platforms were initially lighter $(\mathrm{p}<0.05)$ than those without. The difference was still statistically significant in mid-February, but became nonsignificant at breeding time in midMarch.

When the locomotor activities of the groups were compared on a monthly basis, there were no statistically significant differences (Table 2). However, when the data for the whole experiment were compiled, the overall locomotor activity of the group with platforms proved to be significantly lower $(\mathrm{p}<0.05)$ than that of the controls. Significant increases $(\mathrm{p}<0.001)$ in locomotor activities were also found from January to March in both groups. This increase was higher in males $(\mathrm{p}<0.05)$ than in females. After January, males were also generally more active than females $(\mathrm{p}<0.05)$.

\section{Reproductive performance}

In experiment 1 , one blue fox female in the control group died for an unknown reason just before breeding. Matings were more successful in
Table 3. Comparison of whelping results between blue foxes housed with and without platforms (Exp. 1). Data are given as mean \pm SE. $P>0.05$ for each parameter (Mann-Whitney U-test). V-type platforms were used. Whelping result was calculated at age of 8 weeks (weaning).

\begin{tabular}{lcc}
\hline & Control & Platform \\
\hline Number of breeding females & 59 & 60 \\
Number of mated females & 50 & 56 \\
Mated, \% & 84.7 & 93.3 \\
Barren,\% & 14.0 & 21.4 \\
Lost their pups, \% & 9.3 & 4.5 \\
Pups/breeding female & $7.1 \pm 2.4$ & $7.5 \pm 2.4$ \\
Pups/mated female & $8.4 \pm 2.3$ & $8.1 \pm 2.4$ \\
Pups/whelped female & $9.8 \pm 2.2$ & $10.3 \pm 2.3$ \\
\hline
\end{tabular}

the platform group than in the control group (Table 3). On the other hand, the number of barren (non-producing) females was higher in the platform group. The whelping result was 0.4 pups higher for animals in the platform group than for control animals, if calculated per female kept for breeding, but 0.3 pups lower when calculated per mated female. However, no significant differences existed in any of these reproductive parameters.

\section{Weight gain from weaning to pelting}

There were no significant differences in body weight development between groups (Exp. 2), nor did the final body weights (December 21) of the control $(\mathrm{N}=60)$ and platform groups $(\mathrm{N}=201)$ differ significantly from each other (7.2 \pm 0.7 kg vs. $7.2 \pm 0.6 \mathrm{~kg}$; mean $\pm \mathrm{SD}$ ). Because there were no differences in the platform groups, their data were pooled.

\section{Fur parameters}

In experiment 2 , two different ceilings (platforms $23 \mathrm{~cm}$ and $30 \mathrm{~cm}$ from cage roofs) as well as wooden and plastic-coated wire mesh materials were compared to determine whether these platform constructions affected fur quality parame- 


\section{AGRICULTURAL SCIENCE IN FINLAND}

Korhonen, H.\& Niemelä, P.: Comparison of production results between blue foxes housed with and without platforms

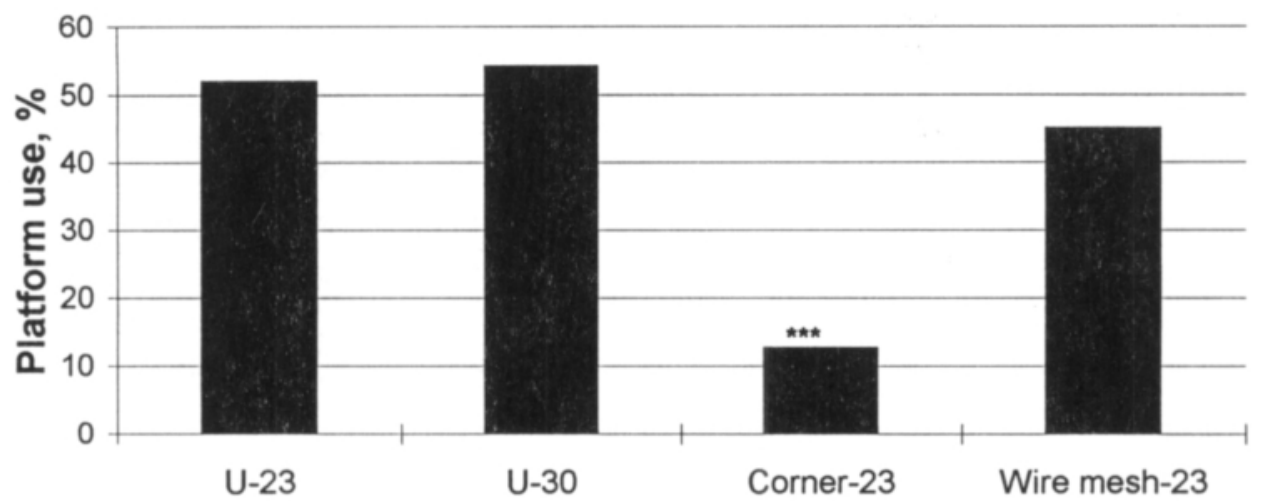

Fig. 2. Comparison of platform use ( $\%$ of observations on the platform) by blue foxes between four construction models. The groups named 23 and 30 indicate the distance from the cage roof in $\mathrm{cm}$. ${ }^{* * *} \mathrm{p}<0.001$ (Kruskal-Wallis test/MannWhitney U-test). See also Table 1.

ters. Platform use during winter fur development (Oct-Nov) was of the same order of magnitude with both ceilings for the wooden $\mathrm{U}$ type and the net type $(p>0.05)$ but the corner type was used significantly less compared to the others $(\mathrm{p}<0.001)$ (Fig. 2). The number of furs showing ventral wear ranged from $9.6 \%$ (corner) to $16.0 \%$ (U-23) per group, there being no significant difference between the platform groups. Ventral wear of the fur of the animals in the control group (without platforms) tended to be lower (6.6\%) than that of the animals with platforms, although statistical confirmation $(\mathrm{p}<0.05)$ was found only in comparison with U-23 (16.0\%). The number of ventrally-worn furs in the animals in the U30 and wire mesh groups was $12.7 \%$ and $10.0 \%$, respectively. Urine stains were only found in the
U-30 group, where $9.1 \%$ of the skins were contaminated with urine.

According to the commercial evaluation scale employed by Finnish Fur Sales Ltd., the clarity and quality of furs were best in animals of the wire mesh group and poorest in the U-30 animals (Table 4). The average price of pelts from the wire mesh group was FIM 40-50 higher than that of other groups. However, the difference was not statistically significant. A weak, but statistically significant, relationship was found between fur quality (Y) and individual platform use (X) during October-November, indicating that fur quality tended to be good when platform use was low and vice versa $(\mathrm{Y}=-0.01 \mathrm{X}+6.06 ; \mathrm{p}<0.05$, $\mathrm{F}=3.84, \mathrm{R}^{2}=0.10$ ). A slightly stronger relationship was found between fur price (Y) and plat-

Table 4. Characteristics of commercial pelt and fur parameters as evaluated by Finnish Fur Sales Ltd. Means with different uppercase letters $(a-b)$ were significantly different $(p<0.05)$ (Kruskal-Wallis test/ Mann-Whitney U-test) (Exp. 2). 23 and 30 in group names indicate the distance from cage roof in $\mathrm{cm}$. All pelts were sold at the same auction (April 1994).

\begin{tabular}{lcccc}
\hline & U-23 & U-30 & Corner-23 & Net-23 \\
\hline Number of pelts & 50 & 55 & 46 & 50 \\
Pelt length,cm & $105.1 \pm 5.9^{\mathrm{ab}}$ & $105.9 \pm 5.4^{\mathrm{ab}}$ & $104.1 \pm 6.0^{\mathrm{b}}$ & $108.5 \pm 7.1^{\mathrm{a}}$ \\
Clarity & $6.3 \pm 1.4^{\mathrm{ab}}$ & $5.9 \pm 1.5^{\mathrm{b}}$ & $6.0 \pm 1.5^{\mathrm{b}}$ & $6.9 \pm 1.6^{\mathrm{a}}$ \\
Fur quality & $5.6 \pm 2.0^{\mathrm{ab}}$ & $5.1 \pm 2.7^{\mathrm{a}}$ & $6.0 \pm 2.2^{\mathrm{ab}}$ & $6.3 \pm 2.0^{\mathrm{b}}$ \\
Pelt price, FIM & $623 \pm 88^{\mathrm{a}}$ & $618 \pm 96^{\mathrm{a}}$ & $616 \pm 94^{\mathrm{a}}$ & $663 \pm 94^{\mathrm{a}}$ \\
\hline
\end{tabular}


Vol. 4: 351-361.

Table 5. Degree of platform dirtiness ( $\%$ of platforms) and number of undamaged platforms (cumulative $\%$ ). Time spent on cleaning platforms is given as seconds/platform/week (Exp. 2). Means with different uppercase letters $(\mathrm{a}-\mathrm{c})$ are significantly different $(\mathrm{p}<0.05)$ (Kruskal-Wallis test/Mann-Whitney U-test). 23 and 30 in group names indicate platform distance from cage roof in $\mathrm{cm}$ (=ceiling).

\begin{tabular}{lrrrr}
\hline & $\mathrm{U}-23$ & $\mathrm{U}-30$ & Corner-23 & Net-23 \\
\hline August & & & & \\
$\quad$ clean platforms & $19.4^{\mathrm{a}}$ & $7.1^{\mathrm{a}}$ & $84.7^{\mathrm{b}}$ & $96.7^{\mathrm{b}}$ \\
slightly dirty & $48.9^{\mathrm{a}}$ & $39.3^{\mathrm{a}}$ & $10.4^{\mathrm{b}}$ & $3.3^{\mathrm{b}}$ \\
moderately dirty & $21.5^{\mathrm{a}}$ & $36.9^{\mathrm{a}}$ & $4.9^{\mathrm{b}}$ & $0^{\mathrm{c}}$ \\
very dirty & $10.1^{\mathrm{a}}$ & $16.7^{\mathrm{a}}$ & $0^{\mathrm{b}}$ & $0^{\mathrm{b}}$ \\
cleaning time & $51^{\mathrm{a}}$ & $82^{\mathrm{b}}$ & $6^{\mathrm{c}}$ & $2^{\mathrm{c}}$ \\
undamaged platforms & $91.7^{\mathrm{a}}$ & $96.7^{\mathrm{a}}$ & $94.5^{\mathrm{a}}$ & $100^{\mathrm{b}}$ \\
September & & & & \\
clean platforms & $54.4^{\mathrm{a}}$ & $21.4^{\mathrm{b}}$ & $86.2^{\mathrm{a}}$ & $100^{\mathrm{c}}$ \\
slightly dirty & $32.3^{\mathrm{a}}$ & $25.7^{\mathrm{a}}$ & $13.8^{\mathrm{a}}$ & $0^{\mathrm{b}}$ \\
moderately dirty & $11.6^{\mathrm{a}}$ & $25.7^{\mathrm{a}}$ & $0^{\mathrm{b}}$ & $0^{\mathrm{b}}$ \\
very dirty & $1.7^{\mathrm{a}}$ & $27.2^{\mathrm{b}}$ & $0^{\mathrm{b}}$ & $0^{\mathrm{c}}$ \\
cleaning time & $23^{\mathrm{a}}$ & $68^{\mathrm{b}}$ & $4^{\mathrm{a}}$ & $0^{\mathrm{c}}$ \\
undamaged platforms & $29.4^{\mathrm{a}}$ & $36.7^{\mathrm{a}}$ & $34.6^{\mathrm{a}}$ & $100^{\mathrm{b}}$ \\
October & & & & \\
clean platforms & $76.6^{\mathrm{a}}$ & $35.7^{\mathrm{b}}$ & $99.0^{\mathrm{a}}$ & $100^{\mathrm{c}}$ \\
slightly dirty & $17.7^{\mathrm{a}}$ & $25.9^{\mathrm{a}}$ & $1.0^{\mathrm{b}}$ & $0^{\mathrm{c}}$ \\
moderately dirty & $4.0^{\mathrm{a}}$ & $20.5^{\mathrm{b}}$ & $0^{\mathrm{a}}$ & $0^{\mathrm{c}}$ \\
very dirty & $1.7^{\mathrm{a}}$ & $17.9^{\mathrm{b}}$ & $0^{\mathrm{a}}$ & $0^{\mathrm{c}}$ \\
cleaning time & $7^{\mathrm{a}}$ & $29^{\mathrm{b}}$ & $0^{\mathrm{a}}$ & $0^{\mathrm{c}}$ \\
undamaged platforms & $1.7^{\mathrm{a}}$ & $0.8^{\mathrm{a}}$ & $9.4^{\mathrm{b}}$ & $100^{\mathrm{c}}$ \\
\hline
\end{tabular}

form use (X) $(\mathrm{Y}=-0.56 \mathrm{X}+647.85$; $\left.\mathrm{p}<0.01, \mathrm{~F}=7.26, \mathrm{R}^{2}=0.12\right)$.

\section{Dirtiness of and damage to platforms}

The number of clean platforms varied significantly $(\mathrm{p}<0.001)$ between the groups (Exp. 2) during August-October (Table 5). During each month, the U-30 type platforms were the dirtiest, and the wire mesh platforms the cleanest. Cleaning time was the highest in the most dirty platforms and vice versa. There was a significant relationship between the quality of fur (Y) and dirtiness of platform (X) (Oct-Nov period) as follows: $\mathrm{Y}=-0.76 \mathrm{X}+6.81(\mathrm{p}<0.001, \mathrm{~F}=16.02$, $\left.\mathrm{R}^{2}=0.15\right)$. Thus, the dirtier the platform, the lower the quality of the fur. There was also a significant, but weaker, relationship between the clarity of fur ( $\mathrm{Y}$ ) and the dirtiness of the platform $(\mathrm{X})$ : $\mathrm{Y}=-0.278 \mathrm{X}+6.55(\mathrm{p}<0.05$; $\left.\mathrm{F}=8.86, \mathrm{R}^{2}=0.10\right)$.

The wire mesh platforms remained undamaged throughout the experiment (Table 5). The number of chewing marks on the other platforms increased significantly with time $(\mathrm{p}<0.001)$. The number of chewing marks on all three wooden platform types was of the same order of magnitude.

\section{Discussion}

Environmental enrichment can be considered the addition of environmental features which increase the complexity of the captive animal en- 


\section{AGRICULTURAL SCIENCE IN FINLAND}

Korhonen, H.\& Niemelä, P.: Comparison of production results between blue foxes housed with and without platforms

vironment, resulting in beneficial effects on behaviour and other aspects of biological functioning (Newberry 1994). In our study, environmental enrichment consisted of placing resting platform inside the otherwise empty cages of farm foxes. Thus, the critical experimental factor here was the presence of the platform.

Our results showed that there was no difference in whelping success between farmed blue foxes raised with and those raised without resting platforms. Although the number of mated females was somewhat higher in the platform group, the greater number of barren females caused the difference between the groups to be nonsignificant. Our conclusions are supported by previous platform experiment (Valtonen and Moss 1983) carried out at two Finnish blue fox farms. On the first farm, the whelping result per mated female in the platform group was 5.73 and in the control group 5.20, with no statistical difference in the means or number of barren females. On the second farm, the corresponding results were 8.82 and 8.38 , respectively. The difference was not significant. The number of barren and aborted females was, however, higher in the platform group (Valtonen and Moss 1983). On the other hand, some studies from Denmark have yielded a somewhat different conclusion. Konnerup-Madsen (1982) found that the whelping result per mated females was higher in the platform group (6.24) than in the control group (5.51). In the experiment of Sönderup (1986), foxes with platforms averaged $7.78 \mathrm{kits} / \mathrm{mated}$ female, but controls only 6.96. However, these whelping results are not unambiguously valid because some of the females were given substantial vitamin supplements during the breeding season. The better whelping success in both Danish experiments was due to the lower number of barren females in the platform groups. Moreover, the different whelping result between platform experiments may have been partly due to differences in the platform types used (Korhonen and Niemelä 1994) or the temperament of the vixens (Kristensen 1988, Bakken et al. 1994). Clarification of these points requires further study.
The locomotor activity of our blue foxes with platforms tended to be somewhat lower than that of the controls. It is possible that the addition of extra equipment such as a platform in a farm cage may limit activity by curtailing the animal's ability to move freely on the cage floor. The extent of this constriction, however, depends on platform construction and ceiling height at least (Harri et al. 1988, Korhonen and Niemelä 1994, Korhonen et al. 1995). It is unclear whether the somewhat minor weight loss noted in our platform animals from January to March might be a result of lower locomotor activity. However, the decrease in activity was so slight that it did not affect whelping success. On the other hand, it is also possible that the presence of the platform in the cage may reduce the need for pronounced activity because the platform as such serves as an extra stimulus (Bakken et al. 1994, Newberry 1994).

Our previous platform experiment during the growing period showed that ventral fur wear was twice as prominent in foxes of the platform group as in the controls (Korhonen and Niemelä 1993). In that experiment, the same result was obtained with three different platform types (V, E, L). In the present study, there was also a tendency for platform use to be associated with ventral fur wear. At its best this was seen in furs of animals with U-type platforms in their cages. Platform use was also highest in this group. The very low amount of platform use seems to explain the low amount of ventral wear in the fur of animals with corner type platforms. Ventral wear was also observed in the control furs but to a lesser extent. Thus, some wear clearly also exists in animals housed without platforms. The reason for this is unknown, but one possibility is the obesity of animals at pelting time (cf. Korhonen and Niemelä 1993).

There were no marked differences in weight development or final body weights between animals in the platform and control groups during the growth period. The result is thus consistent with that of our previous blue fox experiment in which no differences in pelt length and final body weight were found between animals with and 


\section{AGRICULTURAL SCIENCE IN FINLAND}

Vol. 4: 351-361.

without platforms (Korhonen and Niemelä 1993). As a matter of fact, it is rather difficult to see why there should be a difference in growth between the two groups. The more limited space in platform cages may play a role, but at least the present, conventional-sized cages with platforms were large enough to provide normal weight development. On the other hand, the platform can be seen as an environmental enrichment to the cage, providing more complexity and stimuli for behavioural activity (Braastad 1992, Bakken et al. 1994). Such enrichment would be expected to promote wellbeing (Newberry 1994), and thus should not have an adverse effect on growth.

The present platform types were a new type of construction and had not been studied before. Comparison of their use with that of the previous platform types (Harri et al. 1991; Korhonen and Niemelä 1993) showed that more use was made of wire-mesh and U-types but less of the corner type. Thus, if we consider the amount of platform use as a criterion of good platform design, then wire mesh and U-types can be recommended. However, in terms of animal welfare this is obviously not the only important point (Jeppesen and Pedersen 1991). It was recently pointed out that the frequency of platform use by farm foxes does not necessarily express the magnitude of their need for such equipment. According to Bakken et al. (1994), it is important for the fox to have a refuge and an observation platform even if it does not use it often.

From the farmer's point of view, the interesting result is the economic effect of platform construction and material. In this respect, the wire mesh platform was the most cost-effective, as the pelts of foxes from such cages fetched the highest prices, the platforms needed the least cleaning, and the number of dirty and damaged platforms was the lowest. Since differences in fur quality and clarity existed between pelts coming from similar U platform types with two different ceiling heights, it is evident that the ceiling can also affect these commercially valuable fur parameters. In blue foxes, Harri et al.(1988) have observed that a platform distance of $30 \mathrm{~cm}$ from the roof activates defecation on the platform as there is enough space for the appropriate posture, but a distance of $20 \mathrm{~cm}$ prevents defecation as space is too limited. Our findings support this claim as the number of clean platforms was significantly lower in cages with the $\mathrm{U}$ type of platform $30 \mathrm{~cm}$ from the roof than in those with the same type of platform $23 \mathrm{~cm}$ from the roof.

As the results showed, some of the wooden platforms were very dirty, even though they were cleaned once a week. For the commercial farmer cleaning may thus constitute a considerable problem in terms of extra work. Dirty platforms may also cause health problems due to infection. The most common source of foxes' urinary tract infection, for instance, is bacterial invasion from outside sources (Harri et al. 1991). Wooden platforms also involve extra costs because of chewing damage. From our data (Table 5) we estimated that wooden platforms have to be replaced once a year or every other year. Platform dirtiness may also be reflected in both fur quality and clarity, as our results implied. Problems such as these are not encountered with mesh platforms, however. Thus, in light of the present results, wire-mesh platforms would appear to be the obvious choice.

In conclusion, there are no differences in such parameters as whelping result or body weight between farmed blue foxes housed with and those housed without platforms. Wooden platforms can be problematic if the distance to the cage roof is more than $23 \mathrm{~cm}$ because their excessive dirtiness can impair the quality parameters of furs. Wooden platforms also raise costs owing to the extra cleaning needed and platform damage. Both can be avoided by using platforms made of plastic-coated wire. There is little difference in the use foxes make of wooden or wire mesh platforms.

Acknowledgements. Thanks are due to the entire staff of the research station for valuable assistance in carrying out these experiments. Mr Pekka Toikkanen and Mr Aimo JokiHuuki took care of the animals in general and particularly of weighing and mating. Mr Terho Lindqvist saw to their feeding. Mr Pekka Eskeli and Mr Jaakko Huuki arranged 
Korhonen, H.\& Niemelä, P.: Comparison of production results between blue foxes housed with and without platforms

the video recordings. Ms Sanna Moisio and Ms Tiina Huuki analysed the video tapes, and did the scan samplings together with Ms Tuula Jäväjä. Mr Pekka Siirilä kindly

helped with the computer analysis.

\section{References}

Bakken, M., Braastad, B., Harri, M., Jeppesen, L.L. \& Pedersen, V. 1994. Production conditions, behaviour and welfare of farm foxes. Scientifur 18: 233-248.

Berg, H. 1986. Rehutietoutta Turkiselăinkasvattajille. Turkiseläintutkimuksia 23. Suomen Turkiselăinten Kasvattajain Liitto ry. Vaasa, Painopinta Ky. 99 p.

Braastad, B.O. 1992. Progress in the ethology of foxes and mink. Norwegian Journal of Agricultural Sciences (Suppl.) 9: 487-504.

Einarsson, E.J. \& Skrede, A. 1989. Avl og föring av rev. A/S Landbruksforlaget. Engers Boktrykkeri, Otta, Norge. $191 \mathrm{p}$.

European Convention 1991. European Convention for the protection of animals kept for farming purposes. Strasbourg 1976, ETS 87. Recommendation Concerning Fur Animals, 25 June 1991. 19 p.

Finnish Fur Sales' auction catalogue 1994. Vantaa, 1994. $15 \mathrm{p}$

Harri, M., Korhonen, H. \& Mononen, J. 1988. Use of sleeping plates by raccoon dogs and foxes. In: Murphy, B.D. \& Hunter, D.B. (eds.). Biology, Pathology and Genetics of Fur Bearing Animals. Proceedings of the IV International Congress in Fur Animal Production. Ontario, Canada. p. 145-152.

-, Mononen, J., Korhonen, H. \& Haapanen, K. 1991. A study of the use of resting platforms by farmbred blue foxes. Applied Animal Behaviour Science 30: 125-139. -, Mononen, J., Rekilä, T. \& Korhonen, H. 1992. Wholeyear nest boxes and resting platforms for foxes. Norwegian Journal of Agricultural Sciences (Suppl.) 9: 512-519. Jeppesen, L.L. \& Pedersen, V. 1991. Effects of wholeyear nest boxes on cortisol, circulating leucocytes, exploration and agonistic behaviour in the silver fox ( Vulpes vulpes). Behavioural Processes 25: 171-177.
-, \& Pedersen, V. 1992. Correlations between levels of cortisol, behaviour and nest box use in silver fox vixens. Norwegian Journal of Agricultural Sciences (Suppl.) 9: 505-511.

Konnerup-Madsen, H. 1982. Laeforsög med blåraeve. Dansk Pelsdyravl 45: 451.

Korhonen, H. \& Niemelä. P. 1993. Use of resting platforms by growing blue foxes. Scientifur 17: 271-276.

- \& Niemelä, P. 1994. Use of various platforms and nestbox by farmed blue and silver foxes. NJF seminar $\mathrm{nr}$. 253. Skörping, Denmark. p.13.

-, Ketoja, E. \& Niemelä, P. 1995. Comparison of daytime use between platform types, materials, ceilings and experiences in juvenile blue foxes (Alopex lagopus). Applied Animal Behaviour Science (in press).

Kristensen, M.P. 1988. An evaluation of exploratory and fear- motivated behaviour as predictors of reproductive success in silver fox vixens. Scientifur 12: 199-205.

Mononen, J., Harri, M., Rouvinen, K. \& Niemelä, P. 1993. The use of resting platforms by young silver foxes (Vulpes vulpes). Applied Animal Behaviour Science 38: 301-310.

Newberry, R.C. 1994. Environmental enrichment: bringing nature to captivity. 28th Int. Congr. of the ISAE, 3-6 August, 1994, Foulum, Denmark. Proceedings pp. 5167.

Pedersen, V. \& Jeppesen, L.L. 1993. Daytime use of various types of whole-year shelters in farmed silver foxes (Vulpes vulpes) and blue foxes (Alopex lagopus). Applied Animal Behaviour Science 36: 259-273.

Sönderup, M. 1986. Gode laeforhold forbedrer blåraeves hvalpresultat. Dansk Pelsdyravl 49: 774-776.

Valtonen, M. \& Moss, S. 1983. Talvikoppikokeita ketuilla. Turkistalous 55: 634-636. 
Vol. 4: 351-361.

\title{
SELOSTUS
}

\section{Makuuhyllyjen vaikutus tarhattujen sinikettujen tuotantotulokseen}

\author{
Hannu Korhonen ja Paavo Niemelä \\ Maatalouden tutkimuskeskus
}

Tutkimuksessa selvitettiin, eroaako makuuhyllyjen kanssa ja ilman niitä kasvatettujen sinikettujen (Alopex lagopus) tuotantotulos toisistaan. Tulokset osoittivat, että makuuhyllyillä ei ole vaikutusta kettujen painonkehitykseen ja lisääntymiseen. Liikunta-aktiviteetti sen sijaan näytti olevan hieman vähäisempi ketuilla, joiden häkissä on makuuhylly.

Siniketut käyttivät talvikarvan kehitysvaiheeessa loka-marraskuussa eniten puista U-mallista hyllyä, jonka etäisyys katosta oli $30 \mathrm{~cm}(54,1 \%$ havainnoista hyllyllä), ja vähiten puista kulmahyllyä (12,6\%). Hyllyn korkeus ja materiaali vaikuttivat hyllyn likai- suuteen. Matalalla (30 cm katosta) olevat hyllyt olivat likaisimpia ja verkkohyllyt taas puhtaimpia. Hyllyt olivat likaisimpia elokuussa, jolloin niiden puhdistusaika vaihteli välillä 82 sekuntia/hylly (U-30) ja 2 sekuntia/hylly (verkko). Karvan laatu ja puhtaus riippuivat hyllyn likaisuudesta siten, että likaisimmissa hyllyissä laatu ja puhtaus oli huonoin ja päivastoin. Ketut purivat puisia hyllyjä, sen sijaan verkkohyllyt pysyivät ehjinä. Tarhaajan näkökulmasta tarkasteltuna verkkohyllyt näyttävät soveltuvan käytännön olosuhteisiin puisia paremmin. 